Zbigniew Bereszyński

(Państwowy Instytut Naukowy - Instytut Śląski w Opolu)

dr, zbereszynski@wp.pl

\title{
Sowietyzacja życia społecznego w Polsce na przykładzie Śląska Opolskiego w latach 1947-1951
}

19 stycznia 1947 r. odbyły się sfałszowane przez komunistów wybory do Sejmu Ustawodawczego. W ten sposób komuniści uzyskali pozory mandatu społecznego do sprawowania władzy w Polsce. Był to fakt o przełomowym znaczeniu dla dalszego rozwoju sytuacji politycznej w kraju. Zaczął się okres stopniowej sowietyzacji życia publicznego, zmierzającej do ustanowienia totalitarnego systemu politycznego, w którym państwo zespolone w organiczną całość z partią marksistowsko-leninowską miało ściśle kontrolować wszystkie obszary społecznej egzystencji.

Mechanizmy tego procesu są szczególnie łatwe do ukazania na przykładzie tego, co działo się na poziomie lokalnym w poszczególnych częściach kraju. Tematem tego artykułu jest rozwój sytuacji w latach 1947-1950 na Śląsku Opolskim. Pod pojęciem tym rozumiem tzw. rolniczą część obszaru przedwojennej rejencji opolskiej, wchodzącą w latach 1945-1950 w skład ówczesnego województwa śląskiego, a od połowy 1950 r. w skład nowo utworzonego województwa opolskiego.

Po długim okresie politycznego maskowania się Polska Partia Robotnicza zaczęła oficjalnie deklarować się jako partia komunistyczna, dążąca do „dyktatury proletariatu" i realizacji sowieckich wzorców ustrojowych. Po przeprowadzonych 19 stycznia 1947 r. wyborach do Sejmu Ustawodawczego, sfałszowanych przez komunistów ${ }^{1}$, w jej szeregi zaczęli licznie napływać po-

${ }^{1}$ J. Eisler, Czterdzieści pięć lat, które wstrzasnęty Polską. Historia polityczna 1944-1989, Warszawa 2018, s. 98-99; Z. Bereszyński, Referendum ludowe w 1946 r. i wybory do Sejmu Ustawodawczego $w 1947$ r. w zachodnich powiatach województwa ślaskiego w świetle materiałów aparatu bezpieczeństwa, [w:] Referendum ludowe w 1946 roku i wybory do Sejmu Ustawodawczego w 1947 roku na Górnym Ślasku, pod red. A. Dziuroka i M. Świder, Katowice-Warszawa-Opole 2017, s. 150-152. 
lityczni koniunkturaliści, zajmujący wcześniej postawę wyczekującą. Dzięki temu partia ta zaczęła nabierać charakteru masowego. Tak np. w powiecie głubczyckim przed końcem pierwszego kwartału 1947 r. łączna liczba członków PPR wzrosła do około 2300, przy czym tylko w ostatnim miesiącu kwartału przyjęto około sześciuset nowych członków². Przed końcem kwietnia tegoż roku liczba członków PPR w powiecie głubczyckim wzrosła już do $2850^{3}$. W powiecie nyskim przed połową lutego 1947 r. liczebność PPR wzrosła o 340 osoby, osiągając stan 2764 osób $^{4}$. W marcu tegoż roku liczba członków wzrosła do 3335.

Już w 1947 r., w niedługi czas po wyborach komuniści zaczęli działać na rzecz faktycznej likwidacji systemu wielopartyjnego. W pierwszej kolejności doprowadzono do likwidacji organizacyjnych niedobitków Polskiego Stronnictwa Ludowego na Śląsku Opolskim. W marcu 1947 r., w warunkach uprawianego przez komunistów terroru, zakończył działalność Zarząd Powiatowy PSL w Głubczycach - jedyna, obok Zarządu Powiatowego w Opolu, tej rangi struktura organizacyjna PSL na Śląsku Opolskim, jakiej udało się przetrwać okres niezwykle brutalnej kampanii wyborczej. W maju tegoż roku kierowany przez komunistów aparat bezpieczeństwa storpedował próbę reaktywowania lokalnych struktur PSL $\mathrm{w}$ powiecie nyskim 5 .

W tymże roku komuniści zaczęli coraz bardziej ingerować w sprawy personalne Polskiej Partii Socjalistycznej, dążąc do opanowania jej przez działaczy opowiadających się za ścisłą współpracą z PPR, tzw. jednolitofrontowców. Tak np. w sprawozdaniu za październik 1948 r. kierownictwo Powiatowego Urzędu Bezpieczeństwa Publicznego w Strzelcach Opolskich chwaliło się, że PK PPS jest już „opanowany w całości przez element demokratyczny i postępowy"6.

${ }^{2}$ Archiwum Instytutu Pamięci Narodowej - Oddział we Wrocławiu (dalej: AIPN Wr), 07/66, Raport sprawozdawczy [PUBP Głubczyce] za okres od 1 do 30 marca 1947 r., dokument z 29 marca 1947 r., s. 16 [pdf].

${ }^{3}$ Tamże, Raport sprawozdawczy [PUBP Głubczyce] za okres od 1 do 30 kwietnia 1947 r., s. 23 [pdf].

${ }^{4}$ AIPN Wr, 07/452, cz. 1, Raport specjalny [PUBP Nysa], 19 lutego 1947 r., s. 97 [pdf].

${ }^{5}$ Tamże, Raport miesięczny [PUBP Nysa] za maj 1947 r., 29 maja 1947 r., s. 124; tamże, Raport miesięczny [PUBP Nysa] za czerwiec 1947 r., 28 czerwca 1947 r., s. 132 [pdf]. Por. F. Gryciuk, Wtadystaw Zaremba, [w:] Represje wobec wsi i ruchu ludowego (1944-1989), t. 4: Między apologia a negacja, pod red. J. Gmitruka i E. Leniart, Warszawa 2010, s. 33. Niedobitki lokalnych struktur PSL w powiecie opolskim utrzymały się jeszcze do 1949 r., do czasu narzuconego odgórnie zjednoczenia ruchu ludowego. Niestety, ich działalność po 19 stycznia 1947 r. tylko w niewielkim stopniu przypominała aktywność opozycyjną z lat 1945-1946. Por.: A. Dawid, Kulisy rozbicia struktur opolskiego PSL po 19 stycznia 1947 r., [w:] Referendum ludowe w 1946 roku, s. 268-278; tejże, Ernest Zmarzły (1910-1980) - lider opolskiego Polskiego Stronnictwa Ludowego, [w:] Opolanie znani i nieznani. Czasy po II wojnie światowej, cz. 1, pod red. M. Świder, Opole 2017, s. 277-281.

${ }^{6}$ AIPN Wr, 07/452, cz. 1, Raport miesięczny [PUBP w Strzelcach Opolskich dla szefa WUBP w Katowicach] za okres od 1 do 31 października 1948 r., k. 100. 
W marcu 1948 r. krajowe kierownictwo PPS na czele z Józefem Cyrankiewiczem opowiedziało się pod presją komunistów za zjednoczeniem z PPR ${ }^{7}$. Konsekwencją tego było w szczególności faktyczne ubezwłasnowolnienie lokalnych struktur PPS. Tak np. od kwietnia 1948 r. lokalne władze PPS w powiecie prudnickim nie mogły podjąć żadnej decyzji bez uprzedniego porozumienia tzw. trójek partyjnych, powołanych w ramach odgórnie zarządzonej współpracy z PPR P $^{8}$ Szeregi PPS zaczęto „oczyszczać" $z$ „ludzi przeciwstawiających się zbliżeniu i zjednoczeniu obu partii" ${ }^{9}$. W samym tylko powiecie prudnickim w listopadzie 1948 r. zostało wydalonych 318 członków PPS $^{10}$. Przed końcem tegoż miesiąca wykluczono 120 spośród 711 członków PPS $\mathrm{w}$ powiecie głubczyckim ${ }^{11}$. W powiecie nyskim do czasu zjednoczenia z PPR wydalono z PPS łącznie około sześćset osób (dla porównania warto dodać, że w sierpniu 1947 r. miejscowe struktury powiatowe PPS liczyły około dwa tysiące członków) ${ }^{12}$. W powiecie strzeleckim przed końcem listopada 1948 r. z szeregów miejscowej organizacji PPS usunięto z przyczyn politycznych łącznie 357 osób $^{13}$.

W grudniu 1948 r. odpowiednio "oczyszczone” struktury PPS zostały połączone z PPR. W wyniku tego powstała Polska Zjednoczona Partia Robotnicza jako rządząca partia marksistowsko-leninowska ${ }^{14}$.

Na podobnej zasadzie dokonało się zjednoczenie ruchu ludowego. Pod koniec listopada 1949 r. Stronnictwo Ludowe, występujące od 1945 r. jako polityczny sprzymierzeniec PPR, zostało połączone z odpowiednio „oczyszczo-

${ }^{7}$ P. Lipiński, Cyrankiewicz. Wieczny premier, Wołowiec 2016, s. 98.

${ }^{8}$ AIPN Wr, 07/365, Raport miesięczny komendanta powiatowego Milicji Obywatelskiej w Prudniku o sytuacji polityczno-gospodarczej w powiecie za miesiąc kwiecień 1948 r., 3 maja 1948 r., s. 321; tamże, Raport miesięczny komendanta powiatowego Milicji Obywatelskiej w Prudniku o sytuacji polityczno-gospodarczej w powiecie za miesiąc maj 1948 r., 3 czerwca 1948 r., s. 326 [pdf].

${ }^{9}$ Tamże, Sprawozdanie z pracy aparatu polit[yczno]-wych[owawczego] Powiatowej Komendy MO w Prudniku za okres od 3 maja do 3 czerwca 1948 r., s. 331 [pdf].

10 Tamże, Raport miesięczny komendanta powiatowego Milicji Obywatelskiej w Prudniku o sytuacji polityczno-gospodarczej w powiecie za miesiąc listopad 1948 r., 4 grudnia 1948 r., s. 380 [pdf].

11 AIPN Wr, 07/66, Raport miesięczny [PUBP Głubczyce] za okres od 30 października do 29 listopada 1948 r., s. 114 [pdf]; AIPN Wr, 09/898, Charakterystyka kontrwywiadowcza terenu powiatu głubczyckiego, 3 lipca 1956 r. s. 146 [pdf].

${ }^{12}$ AIPN Wr 07/452, cz. 1, Raport miesięczny [PUBP Nysa] za sierpień 1947 r., s. 145; tamże, Raport miesięczny [PUBP Nysa] za grudzień 1948 r., s. 282; tamże, Raport miesięczny [PUBP Nysa] za kwiecień 1947 r., 8 (9?) maja 1947 r., s. 113 [pdf].

13 Tamże, Raport miesięczny [PUBP w Strzelcach Opolskich dla szefa WUBP w Katowicach] za okres od 1 do 30 listopada 1948 r., dokument z 29 listopada 1948 r., k. 110.

${ }^{14}$ Por. J. Eisler, dz. cyt., s. 120-124; W. Roszkowski, Najnowsza historia Polski 1945-1980, Warszawa 2003, s. 142-143, 150-151. 
nymi" niedobitkami PSL, w wyniku czego powstało Zjednoczone Stronnictwo Ludowe $^{15}$. Zmianę tę poprzedziły czystki polityczne w szeregach SL ${ }^{16}$.

"Zjednoczony" ruch ludowy znalazł się pod ścisłą kuratelą polityczną PZPR. Tak np. kandydaci do Powiatowego Komitetu Wykonawczego ZSL w Strzelcach Opolskich byli typowani przez Wydział Organizacyjny Wojewódzkiego Komitetu ZSL w Katowicach w porozumieniu z byłym Zarządem Powiatowym SL oraz I sekretarzem Komitetu Powiatowego PZPR ${ }^{17}$.

W krótkim czasie komuniści zlikwidowali również resztki samodzielności Stronnictwa Demokratycznego. Tak np. w listopadzie 1948 r. na zjeździe powiatowym SD w Prudniku wybrano „nowy zarząd [...] w skład którego weszli ludzie o orientacji lewicowej", niebudzący zastrzeżeń PPR ${ }^{18}$.

Zjednoczone Stronnictwo Ludowe i Stronnictwo Demokratyczne zostały sprowadzone do rangi politycznych satelitów PZPR. Wykluczona była ich rywalizacja polityczna z PZPR, wobec czego można mówić o faktycznym ustanowieniu systemu monopartyjnego z zachowanymi ze względów socjotechnicznych reliktami politycznego pluralizmu.

Bardzo szybko zaczęto ustanawiać również totalitarne porządki w odniesieniu do młodzieży. W pierwszych miesiącach $1948 \mathrm{r}$. wprowadzono w życie system pracy przymusowej i szkolenia wojskowego $\mathrm{w}$ ramach Powszechnej Organizacji "Służba Polsce”, do której powoływano młodzież w wieku od 16 do 21 lat. W lipcu 1948 r. zjednoczono odgórnie ruch młodzieżowy, tworząc Związek Młodzieży Polskiej, wzorowany na sowieckim „Komsomole”19.

Latem 1948 r. za sprawą komunistów nasiliły się czystki polityczne w lokalnym aparacie władzy, administracji, radach narodowych i spółdzielczości $^{20}$. Dla przykładu w listopadzie tegoż roku w poszczególnych gminach po-

${ }^{15}$ W. Roszkowski, dz. cyt., s. 136-137 i 150.

${ }^{16}$ AIPN Wr, 07/66, Raport miesięczny Pow[iatowego] Urzędu Bezp[ieczeństwa] Publ[icznego] w Głubczycach za okres od 1 stycznia do 1 lutego 1950 r., dokument z 2 lutego 1950 r., s. 204 [pdf].

17 AIPN Wr, 07/44, Raport miesięczny [PUBP w Strzelcach Opolskich dla szefa WUBP w Katowicach] za okres od 1 do 31 grudnia 1949 r., k. 162; tamże, Raport miesięczny [PUBP w Strzelcach Opolskich dla szefa WUBP w Katowicach] za okres od 1 do 31 stycznia 1950 r., dokument z 3 lutego 1950 r., k. 175; tamże, Raport miesięczny [PUBP w Strzelcach Opolskich dla szefa WUBP w Katowicach] za okres od 1 do 28 lutego 1950 r., dokument z 26 lutego 1950 r., k. 193.

${ }^{18}$ AIPN Wr, 07/365, Raport miesięczny komendanta powiatowego Milicji Obywatelskiej w Prudniku o sytuacji polityczno-gospodarczej w powiecie za miesiąc listopad 1948 r., 4 grudnia 1948 r., s. 380 [pdf].

${ }^{19}$ W. Roszkowski, dz. cyt., s. 137-138; A.L. Sowa, Historia polityczna Polski 1944-1991, Kraków 2011, s. 142-143; L. Szuba, Działalność Powszechnej Organizacji "Stużba Polsce” w latach 1948-1956, [w:] Niezależny ruch młodzieżowy w Polsce po drugiej wojnie światowej (1945-2001), pod red. R. Sudzińskiego, Toruń 2005, s. 13-15.

${ }^{20}$ AIPN Wr, 07/452, cz. 1, Raport [PUBP Nysa] za sierpień 1948 r., 30 VIII 1948 r., s. 246 [pdf]. 
wiatu nyskiego powołano pięcioosobowe grupy specjalne (,piątki”), złożone z ludzi „o wyraźnym obliczu politycznym” i mające „za zadanie oczyszczenie miejscowego aparatu" samorządowego ${ }^{21}$. W połowie grudnia tegoż roku rozpoczęły się czystki w gminnych spółdzielniach Samopomocy Chłopskiej $\mathrm{w}$ powiecie nyskim ${ }^{22}$.

W działaniach tych aktywnie uczestniczył aparat bezpieczeństwa, ściśle współpracujący z miejscowymi władzami partyjnymi PPR i PZPR. Tak np. w październiku 1948 r. PUBP w Głubczycach wspólnie z Komitetem Powiatowym PPR „wytypował do usunięcia ludzi na kierowniczych stanowiskach na terenie wsi". Już przed końcem miesiąca zdążono zrealizować te ustalenia w odniesieniu do trzech wójtów, dwóch sołtysów oraz licznych sekretarzy gminnych i referentów podatkowych ${ }^{23}$. W tymże miesiącu Komitet Powiatowy PPR i PUBP w Nysie wspólnie wytypowały pierwszą grupę 108 osób do usunięcia z miejscowego aparatu administracyjnego (przeważnie $\mathrm{z}$ rad narodowych ${ }^{24}$.

Przed końcem listopada 1948 r. PUBP w Głubczycach „,za pośrednictwem Polskiej Partii Robotniczej wpłynął na usunięcie czterdziestu członków gminnych i miejskich rad narodowych, w tym trzech przewodniczących gminnych i miejskich rad narodowych". W rolniczych częściach powiatu usunięto ze stanowisk jednego sołtysa i 110 radnych, w tym pięciu przewodniczących gminnych rad narodowych ${ }^{25}$. W tym samym czasie wytypowano do usunięcia jednego burmistrza, trzech wójtów i kilkunastu urzędników ${ }^{26}$.

Jesienią 1948 r. pod polityczną kuratelą komunistów znalazły się także gminne struktury Samopomocy Chłopskiej. Lokalne władze PPR we współpracy z UB ściśle kontrolowały przebieg wyborów do gminnych zarządów SCh. Referaty rolne komitetów powiatowych PPR typowały kandydatów w uzgodnieniu z referatami IV poszczególnych PUBP, a osoby ośmielające się występować z innymi propozycjami personalnymi były represjonowane przez aparat bezpieczeństwa ${ }^{27}$.

${ }^{21}$ Tamże, Raport miesięczny [PUBP Nysa] za listopad 1948 r., 1 XII 1948 r., s. 271 [pdf].

22 Tamże, Raport miesięczny [PUBP Nysa] za grudzień 1948 r., 29 XII 1948 r., s. 291; tamże, Raport miesięczny [PUBP Nysa] za styczeń 1949 r., 28 I 1949 r., s. 294 [pdf].

${ }^{23}$ AIPN Wr, 07/66, Raport miesięczny o pracy PUBP w Głubczycach na terenie wsi, 29 października 1948 r., s. 108; tamże, Raport miesięczny [PUBP Głubczyce] za okres od 30 września do 30 października 1948 r., dokument z 29 października 1948 r., s. 111 [pdf].

${ }^{24}$ AIPN Wr, 07/452, cz. 1, Raport miesięczny [PUBP Nysa] za październik 1948 r., 30 października 1948 r., s. 262 [pdf].

${ }^{25}$ AIPN Wr, 07/66, Raport miesięczny o pracy PUBP w Głubczycach na terenie wsi za okres od 29 października do 29 listopada 1948 r., s. 119-120 [pdf].

${ }^{26}$ Tamże, Raport miesięczny [PUBP Głubczyce] za okres od 30 października do 29 listopada 1948 r., s. 115 [pdf].

${ }^{27}$ AIPN Wr, 07/452, cz. 1, Raport miesięczny PUBP Nysa [za październik 1948 r.], 6 listopada 1948 r., s. 256; tamże, Raport miesięczny [PUBP Nysa] za listopad 1948 r., 1 listopada 1948 r., 
W tym samym czasie zaczęło się przekształcanie szkół w instrument ideologicznego wychowania młodego pokolenia. W 1948 r. gruntownie przekształcono system oświatowy, dokonując w szczególności likwidacji gimnazjów. Odtąd po ukończeniu siedmioletniej szkoły podstawowej młodzież mogła kontynuować naukę $\mathrm{w}$ liceach lub szkołach zawodowych różnego szczebla ${ }^{28}$. Przystąpiono do stopniowego rugowania nauczania religii ze szkół. W 1949 r., na zasadzie połączenia Robotniczego Towarzystwa Przyjaciół Dzieci oraz Chłopskiego Towarzystwa Przyjaciół Dzieci, utworzono Towarzystwo Przyjaciół Dzieci, finansowane bezpośrednio z budżetu Ministerstwa Oświaty. Pod patronatem TPD powoływano kolejne szkoły bez nauczania religii ${ }^{29}$.

Ściśle łączył się z tym nowy, konfrontacyjny kurs władz państwowych wobec Kościoła. W 1948 r. przystąpiono do usuwania krzyży i innych symboli religijnych ze szkół oraz zakładów pracy. W 1949 r. usunięto kapelanów ze szpitali państwowych, a na przełomie lat 1949 i 1950 upaństwowiono placówki szpitalne działające pod patronatem zgromadzeń zakonnych i fundacji kościelnych. Przykładem tych działań może być dokonana w 1949 r. nacjonalizacja szpitala św. Wojciecha w Opolu i miejscowych zakładów opiekuńczych, prowadzonych przez siostry franciszkanki. W tymże roku upaństwowiono również szpital psychiatryczny w Branicach, prowadzony do tego czasu przez kościelną Fundację Najświętszej Marii Panny ${ }^{30} .5$ sierpnia 1949 r. wydano przewrotnie zatytułowany dekret o ochronie wolności sumienia i wyznania, przewidujący w szczególności karę więzienia za tzw. nadużywanie wolności wyznania ${ }^{31}$. We wrześniu tegoż roku, wraz z utworzeniem Związku Bojowników o Wolność i Demokrację (na zasadzie odgórnego zjednoczenia organizacji kombatanckich), narodził się inspirowany przez władze komunistyczne ruch tzw. księży patriotów, reprezentowany przez komisje księ-

s. 274; tamże, Raport miesięczny PUBP Nysa [za listopad 1948 r.], 30 listopada 1948 r., s. 277278; tamże, Raport miesięczny [PUBP Nysa] za grudzień 1948 r., 29 grudnia 1948 r., s. 287; tamże, Raport miesięczny PUBP Nysa za grudzień 1948 r., 29 grudnia 1948 r., s. 290-291 [pdf].

${ }^{28}$ J. Król, Reforma oświatowa z 1948 roku: uwarunkowania społeczno-polityczne, założenia i realizacja, „Prace Naukowe Akademii im. Jana Długosza w Częstochowie. Pedagogika” 2005, t. 24, s. 559-560.

${ }^{29}$ Archiwum Państwowe w Opolu (dalej: APO), akta Komitetu Wojewódzkiego Polskiej Zjednoczonej Partii Robotniczej (dalej: KW PZPR) w Opolu, 250, Protokół nr 36/51 z posiedzenia Egzekutywy Komitetu Wojewódzkiego PZPR w Opolu odbytego 17 sierpnia 1951 r., s. 9697; tamże, Sprawozdanie z działalności Okręgu Opolskiego TPD za pierwsze półrocze $1951 \mathrm{r}$. (do dn. 31 lipca 1951 r.), s. 112-114. Por. J. Żaryn, Kościót w PRL, Warszawa 2004, s. 18-21, 27.

${ }^{30}$ Zarys historii szpitala w Branicach, http://www.caritaschrysti-branice.com/historia-szpi tala-w-branicach?showall=\&start=2 (dostęp 15 października 2017 r.).

${ }^{31}$ Dekret z dnia 5 sierpnia 1949 r. o ochronie wolności sumienia i wyznania, Dziennik Ustaw 1949, nr 45, poz. 334. Por. H. Dominiczak, Organy bezpieczeństwa PRL 1944-1990, Warszawa 1997, s. 103. 
ży przy Zarządzie Głównym i zarządach okręgowych ZBoWiD, a spełniający funkcje dywersyjne wobec hierarchii kościelnej.

23 stycznia $1950 \mathrm{r}$. władze komunistyczne podporządkowały sobie, na zasadzie wrogiego przejęcia, katolicką organizację dobroczynną „Caritas”, ustanawiając w niej zarząd komisaryczny. Już w styczniu 1950 r. zaczęły powstawać nowe władze tej organizacji, kompletowane $\mathrm{z}$ odpowiednio dobranych nastawionych katolików świeckich i przedstawicieli duchowieństwa ${ }^{32}$.

W sierpniu 1945 r. na obszarze byłej rejencji opolskiej została ustanowiona tymczasowa polska administracja kościelna - Administracja Apostolska Śląska Opolskiego z ośrodkiem w Opolu na czele z ks. infułatem Bolesławem Kominkiem ${ }^{33}$. 26 stycznia $1951 \mathrm{r}$. ten ostatni, podobnie jak inni administratorzy apostolscy na obszarze tzw. Ziem Odzyskanych, został usunięty siłą ze stanowiska $\mathrm{w}$ ramach zarządzonej przez władze państwowe likwidacji stanu tymczasowości polskich władz kościelnych. Miejsce Administracji Apostolskiej zajął Ordynariat Śląska Opolskiego na czele z wybranym pod presją władz państwowych ks. Emilem Kobierzyckim ${ }^{34}$.

Ofensywa polityczna komunistów obejmowała także zawłaszczanie przestrzeni publicznej poprzez narzucanie nowego nazewnictwa ulic i placów. Tak np. w 1949 r. Egzekutywa Komitetu Miejskiego PZPR w Opolu zaczęła występować z kolejnymi wnioskami w tym zakresie pod adresem Miejskiej

${ }^{32}$ Archiwum Instytutu Pamięci Narodowej w Warszawie (dalej: AIPN), 1510/913, M. Łukasiński, „Ruch społecznie postępowy księży (w oparciu o działalność Zrzeszenia Katolików „Caritas « w województwie katowickim)", praca magisterska napisana w 1982 r. w Akademii Spraw Wewnętrznych w Warszawie pod kierunkiem naukowym płk dr Józefy Siemaszkiewicz, s. 75-76 [pdf];J. Żaryn, Dzieje Kościoła katolickiego w Polsce (1944-1989), Warszawa 2002, s. 101-102; tegoż, Kościót w PRL, s. 24; A. Dudek, R. Gryz, Komuniści i Kościót w Polsce (1945-1989), Kraków 2006, s. 48-49; R. Żurek, Kościót rzymskokatolicki w Polsce wobec Ziem Zachodnich i Pótnocnych 19451948, Szczecin-Warszawa-Wrocław 2015, s. 135-136.

33 J. Kopiec, Dzieje Kościoła katolickiego na Ślasku Opolskim, Opole 1991, s. 109 i 128-130; A. Hanich, Likwidacja "stanu tymczasowości administracji kościelnej" na Śląsku Opolskim przez władze komunistyczne w 1951 r., „Śląsk Opolski” 2003, nr 2, s. 24; tegoż, Czas przełomu. Kościót katolicki na Śląsku Opolskim w latach 1945-1946, Opole 2008, s. 215-216, 220-224; tegoż, Dekanaty i parafie Administracji Apostolskiej Śląska Opolskiego w latach 1945-1946, Opole 2009, s. 21; Z. Zieliński, S. Bober, Kościót w Polsce 1944-2007, Poznań 2009, s. 39, 42-43; R. Żurek, dz. cyt., s. 358, 361.

${ }^{34}$ A. Hanich, Likwidacja "stanu tymczasowości...", s. 26-27; A. Hanich, A. Sitek, Wysiedlenie śląskich księży i sióstr zakonnych ze Ślaska Opolskiego w 1954 r., [w:] Stalinizm i rok 1956 na Górnym Ślasku, pod red. A. Dziuroka, B. Linka i K. Tarki, Katowice-Opole-Kraków 2007, s. 145-146; A. Sitek, Organizacja i kierunki działalności Kurii Administracji Apostolskiej Ślaska Opolskiego w latach 1945-1956, Wrocław 1986, s. 97; J. Żaryn, Dzieje Kościoła, s. 122-123; Z. Bereszyński, B. Linek, Ksiądz Emil Kobierzycki (1892-1963): komunistyczny ordynariusz?, [w:] Górny Ślask w Polsce Ludowej, t. 2: Przywódcy - bohaterowie - wrogowie, pod red. A. Dziuroka i B. Linka, Katowice-Opole 2017, s. $162-163$. 
Rady Narodowej ${ }^{35}$. W kwietniu 1951 r. Egzekutywa KM PZPR w Opolu podjęła decyzję o przemianowaniu 25 ulic i jednego placu na terenie miasta ${ }^{36}$.

Równolegle z ofensywą ideologiczną i polityczną postępowały uwarunkowane ideologicznie zmiany w życiu gospodarczym. W latach 1947-1949, w ramach tzw. bitwy o handel, komuniści doprowadzili do likwidacji niemal całego handlu prywatnego ${ }^{37}$. Latem 1947 r. zaczęto wymierzać kupcom surowe kary za brak cenników. Tzw. społeczne komisje kontroli cen stosowały w takich przypadkach karę aresztu bądź kary pieniężne. Obciążano kupców drastycznie podniesionymi podatkami, a także wyższymi czynszami za użytkowanie lokali mieszkalnych. Nakładano wysokie kary finansowe za faktyczne czy rzekome uprawianie praktyk spekulacyjnych, a także utrudniano dostęp do tanich towarów. Jednocześnie kupcy musieli konkurować ze sklepami spółdzielczymi i domami towarowymi, oferującymi artykuły żywnościowe oraz tekstylne po zaniżonych cenach. Zdesperowani handlowcy likwidowali sklepy i wstępowali do spółdzielni, oddając do ich dyspozycji swoje miejsca pracy. Przebieg i efekty tego procesu dobrze ilustrują dane liczbowe dla Opola, gdzie „udział handlu uspołecznionego w rozprowadzeniu masy towarowej" wzrastał stopniowo z 15 proc. w 1946 do 35 proc. w 1947, 55 proc. w 1948 oraz 80 proc. w 1949 r. $^{38}$

W tym samym mniej więcej czasie zaczęły narastać napięcia społeczne na wsi w związku ze ściąganiem od chłopów podatku gruntowego i składek na Fundusz Oszczędnościowy Rolnictwa. Wobec opornych rolników zaczęto stosować postępowanie egzekucyjne. Poborcy podatkowi zajmowali inwentarz żywy - bydło i nierogaciznę $e^{39}$.

W lipcu 1948 r. na posiedzeniu plenarnym Komitetu Centralnego PPR, w duchu nowego kursu politycznego, zapowiedziano ostrą walkę klasową z elementami gospodarki kapitalistycznej, a w ramach tego w szczególności podjęcie działań na rzecz rozwoju spółdzielczości produkcyjnej na wsi.

${ }^{35}$ APO, akta Komitetu Miejskiego Polskiej Zjednoczonej Partii Robotniczej (dalej: KM PZPR) w Opolu, 50/IV/1a, Protokół nr 18 z posiedzenia Egzekutywy Komitetu Miejskiego PZPR w Opolu z 12 czerwca 1949 r., b.p.; tamże, Protokół nr 35 z posiedzenia Egzekutywy Komitetu Miejskiego PZPR w Opolu odbytego 5 października 1949 r., b.p.; tamże, Protokół nr 36 z posiedzenia Egzekutywy Komitetu Miejskiego PZPR w Opolu odbytego 5 października 1949 r., b.p.

${ }^{36}$ APO, KM PZPR w Opolu, 50/IV/3, Protokół z posiedzenia Egzekutywy KM PZPR w Opolu odbytego 26 kwietnia 1951 r., dokument z 3 maja 1951 r., b.p.

${ }^{37}$ A.L. Sowa, dz. cyt., s. 104.

${ }^{38}$ APO, KM PZPR w Opolu, 50/IV/1, Analiza działalności handlu uspołecznionego, [maj 1950 r.], b.p.

${ }^{39}$ AIPN Wr, 07/63, Sprawozdanie miesięczne Referatu IV-go PUBP w Głubczycach po linii S[ekcji] V-tej [Wydziału IV] WUBP [Katowice], 24 grudnia 1949 r., s. 175 [pdf]; AIPN Wr, 07/66, Raport miesięczny [PUBP Głubczyce] za okres od 30 października do 29 listopada 1948 r., s. 116 [pdf]. 
W 1949 r. powołano Państwowe Gospodarstwa Rolne jako polski odpowiednik sowchozów i opracowano wzorcowe statuty spółdzielni produkcyjnych, mających stanowić lokalny odpowiednik kołchozów (analogii takich unikano jednak w oficjalnej propagandzie $)^{40}$. W ślad za tym przystąpiono do organizowania kolejnych spółdzielni produkcyjnych.

Działania na rzecz kolektywizacji rolnictwa od początku spotykały się z najrozmaitszymi przejawami oporu społecznego. Szczególnie silny opór wobec kolektywizacji rolnictwa notowano wśród rdzennej ludności śląskiej, a także wśród Polaków przesiedlonych z przedwojennych Kresów Wschodnich, którzy mieli już okazję zetknąć się z kołchozami ${ }^{41}$.

Postępująca sowietyzacja życia społecznego okazała się bardzo poważną przeszkodą na drodze do społecznej integracji Śląska Opolskiego. Takie fakty i zjawiska, jak walka z Kościołem czy działania na rzecz kolektywizacji rolnictwa, skutkowały umocnieniem postaw proniemieckich wśród rdzennej ludności śląskiej. Tak np. według materiałów UB z początku lat pięćdziesiątych, ks. Joseph Spilla, wieloletni proboszcz w Łanach w powiecie kozielskim, miał mówić, że nie szanuje „,takiej Polski jak obecnie. Kiedyś był [...] Polakiem, ale obecnie, po prześladowaniach siedmioletnich, nie czuje się już nim. Tak samo jak on myślą wszyscy Ślązacy, czego najlepszym dowodem jest fakt, że Polska nie pozyskała ich sobie i nie pozyska" 42 .

Władze komunistyczne reagowały represjami na szerzące się w różnych środowiskach przejawy oporu społecznego. Już po kilku latach, w obliczu takich faktów, jak powstanie robotnicze w Poznaniu w czerwcu 1956 r., były jednak zmuszone pójść na ustępstwa wobec społeczeństwa i dopuścić do częściowej liberalizacji życia publicznego ${ }^{43}$.

${ }^{40}$ M. Krajewski, Historia gospodarcza Polski do 1989 roku. Zarys problematyki, Włocławek 2000, S. 455 .

${ }^{41} \mathrm{~W}$ połowie listopada 1954 r. w całym województwie opolskim było 510 spółdzielni produkcyjnych, zrzeszających łącznie 16506 członków. Spółdzielni zrzeszających ludność pochodzenia miejscowego było jednak tylko 29, a łączna liczba ich członków wynosiła zaledwie 498. Było także 55 spółdzielni zrzeszających ludność mieszanego pochodzenia i mających w swoim składzie tylko 421 osób pochodzenia rodzimego. APO, KW PZPR w Opolu, 285, Informacja o stanie rozwoju spółdzielni produkcyjnych w świetle Uchwały Rady Ministrów z dnia 23 lutego 1954 r., Uchwały Rady Spółdzielczości Produkcyjnej z dnia 3 maja 1954 r. oraz przygotowania do zamknięć rocznych w spółdzielniach produkcyjnych, [listopad 1954 r.], s. 13.

${ }^{42}$ AIPN Wr, 09/106, Analiza sytuacji po linii kleru autochtonicznego, b.d., s. 16 [pdf].

${ }^{43}$ Por. J. Eisler, dz. cyt., s. 161-195; Z. Bereszyński, Przełom polityczny w wymiarze regionalnym. Październik'56 i jego następstwa na przykładzie województwa opolskiego, [w:] Artificem commendat opus. Region - Pamieć - Polityka. Studia i materiaty ofiarowane profesor Danucie Kisielewicz, pod red. E. Ganowicz, Opole 2018, s. 53-60. 


\section{Bibliografia}

\section{Źródła archiwalne}

Archiwum Instytutu Pamięci Narodowej w Warszawie

Archiwum Instytutu Pamięci Narodowej - Oddział we Wrocławiu

Archiwum Państwowe w Opolu

- akta Komitetu Miejskiego PZPR w Opolu

- akta Komitetu Wojewódzkiego PZPR w Opolu

\section{Źródła drukowane}

Dziennik Ustaw, 1949.

\section{Opracowania}

Bereszyński Z., Referendum ludowe w 1946 r. i wybory do Sejmu Ustawodawczego w 1947 r. w zachodnich powiatach województwa śląskiego w świetle materiałów aparatu bezpieczeństwa, [w:] Referendum ludowe w 1946 roku i wybory do Sejmu Ustawodawczego w 1947 roku na Górnym Śląsku, pod red. A. Dziuroka i M. Świder, Katowice-Warszawa-Opole 2017, s. 110-175.

Bereszyński Z., Linek B., Ksiadz Emil Kobierzycki (1892-1963): komunistyczny ordynariusz?, [w:] Górny Śląsk w Polsce Ludowej, t. 2: Przywódcy - bohaterowie - wrogowie, pod red. A. Dziuroka i B. Linka, Katowice-Opole 2017, s. 154-172.

Dawid A., Kulisy rozbicia struktur opolskiego PSL po 19 stycznia 1947 r., [w:] Referendum ludowe w 1946 roku i wybory do Sejmu Ustawodawczego w 1947 roku na Górnym Śląsku, pod red. A. Dziuroka i M. Świder, Katowice-Warszawa-Opole 2017, s. 256-280.

Dawid A., Ernest Zmarzty (1910-1980) - lider opolskiego Polskiego Stronnictwa Ludowego, [w:] Opolanie znani i nieznani. Czasy po II wojnie światowej, cz. 1, pod red. M. Świder, Opole 2017, s. 269-290.

Dominiczak H., Organy bezpieczeństwa PRL 1944-1990, Warszawa 1997.

Dudek A., Gryz R., Komuniści i Kościót w Polsce (1945-1989), Kraków 2006.

Eisler J., Czterdzieści pięć lat, które wstrząsnęty Polską. Historia polityczna 1944-1989, Warszawa 2018.

Gryciuk F., Władystaw Zaremba, [w:] Represje wobec wsi i ruchu ludowego (1944-1989), t. 4: Między apologia a negacja, pod red. J. Gmitruka i E. Leniart, Warszawa 2010, s. 197-216.

Hanich A., Likwidacja "stanu tymczasowości administracji kościelnej" na Śląsku Opolskim przez władze komunistyczne w 1951 r., „Śląsk Opolski” 2003, nr 2, s. 24-30.

Hanich A., Czas przełomu. Kościót katolicki na Śląsu Opolskim w latach 1945-1946, Opole 2008.

Hanich A., Dekanaty i parafie Administracji Apostolskiej Śląska Opolskiego w latach 1945-1946, Opole 2009.

Hanich A., Sitek A., Wysiedlenie śląskich księży i sióstr zakonnych ze Śląska Opolskiego w 1954 r., [w:] Stalinizm i rok 1956 na Górnym Śląsku, pod red. A. Dziuroka, B. Linka i K. Tarki, KatowiceOpole-Kraków 2007, s. 145-207.

Kopiec J., Dzieje Kościoła katolickiego na Śląsku Opolskim, Opole 1991.

Krajewski H., Historia gospodarcza Polski do 1989 roku. Zarys problematyki, Włocławek 2000.

Król J., Reforma oświatowa z 1948 roku: uwarunkowania społeczno-polityczne, założenia i realizacja, „Prace Naukowe Akademii im. Jana Długosza w Częstochowie. Pedagogika” 2005, t. 24, s. 555-566.

Lipiński P., Cyrankiewicz. Wieczny premier, Wołowiec 2016.

Roszkowski W., Najnowsza historia Polski 1945-1980, Warszawa 2003.

Sitek A., Organizacja i kierunki działalności Kurii Administracji Apostolskiej Śląska Opolskiego w latach 1945-1956, Wrocław 1986.

Sowa A.L., Historia polityczna Polski 1944-1991, Kraków 2011. 
Szuba L., Działalność Powszechnej Organizacji "Stużba Polsce” w latach 1948-1956, [w:] Niezależny ruch młodzieżowy w Polsce po drugiej wojnie światowej (1945-2001), pod red. R. Sudzińskiego, Toruń 2005, s. 11-35.

Zarys historii szpitala w Branicach, http://www.caritaschrysti-branice.com/historia-szpitala-wbranicach?showall=\&start=2 (dostęp 15 października 2017 r.).

Zieliński Z., Bober S., Kościót w Polsce 1944-2007, Poznań 2009.

Żaryn J., Dzieje Kościoła katolickiego w Polsce (1944-1989), Warszawa 2002.

Żaryn J., Kościót w PRL, Warszawa 2004.

Żurek R., Kościót rzymskokatolicki w Polsce wobec Ziem Zachodnich i Pótnocnych 1945-1948, SzczecinWarszawa-Wrocław 2015.

Zbigniew Bereszyński

\title{
Sowietyzacja życia społecznego w Polsce na przykładzie Śląska Opolskiego w latach 1947-1951
}

\begin{abstract}
Streszczenie
Sfałszowane przez komunistów wybory do Sejmu Ustawodawczego w styczniu 1947 r. zapoczątkowały okres stopniowej sowietyzacji życia społecznego w Polsce. Proces ten zmierzał do ustanowienia totalitarnego systemu politycznego na wzór sowiecki. Dobrą ilustrację mechanizmów tego procesu stanowi rozwój sytuacji w latach 1947-1950 na Śląsku Opolskim. Postępująca sowietyzacja życia społecznego okazała się bardzo poważną przeszkodą na drodze do społecznej integracji Śląska Opolskiego. Takie fakty i zjawiska, jak walka z Kościołem czy działania na rzecz kolektywizacji rolnictwa, skutkowały umocnieniem postaw proniemieckich wśród rdzennej ludności śląskiej. Władze komunistyczne reagowały represjami na szerzące się w różnych środowiskach przejawy oporu społecznego. Już po kilku latach, w obliczu takich faktów, jak powstanie robotnicze w Poznaniu w 1956 r., były jednak zmuszone pójść na ustępstwa wobec społeczeństwa i dopuścić do częściowej liberalizacji życia publicznego.
\end{abstract}

Słowa kluczowe: Śląsk Opolski, życie społeczne, sowietyzacja, komuniści, system totalitarny

\section{Sovietization of social life in Poland as exemplified by the Opole Silesia region in the years 1947-1951}

\begin{abstract}
Parliamentary elections of January 1947, rigged by communists, began the process of gradual Sovietization of social life in Poland. It aimed at establishing a totalitarian political system, modeled after the Soviet Union. The events which took place in the Opole Silesia region in the years 1947-1950 are a great illustration of this process. Progressive Sovietization of the social life became a major obstacle in the process of achieving social integration in the Opole Silesia. Actions such as a fight with the Catholic Church or creating collective farms resulted with stronger proGerman attitudes among native inhabitants. Communist authorities reacted to manifestations of social resistance among various groups with repressions. However, within a few years, faced
\end{abstract}


with events such as the people's uprising in Poznan in 1956, they were forced to attenuate their policy toward the society and allow for partial liberalization of social life.

Key words: Opole Silesia, Sovietization, communists, totalitarian system 